\title{
POLISH HISTORIOGRAPHY AND ARCHAEOLOGY ON THE MECHANISMS BEHIND THE FORMATION OF THE PIASTS’ REGNUM*
}

This paper discusses the hypotheses developed by Polish researchers on the mechanisms behind the formation of the Piast state. All issues are discussed from the perspective of medieval history, the views of which were until recently prominent in the literature on the subject, and also from the perspective of the more recent findings of early medieval archaeology. The proposals tabled by archaeologists from particular Polish research centres (in Poznań, Warsaw and Wroclaw) are confronted with the results of historical research. A representative of the Poznań centre, the author presents his ideas on the subject as based, e.g., on the results of absolute dating, which are not always consistent with the views of other scholars.

KEY WORDS: Poland, Early Middle Ages, Piast state, Early State concept, historiography, archaeology, cultural and historical anthropology

Recently there has been growing interest in the process of state formation across the European Barbaricum, i.e., in the mechanisms behind the transition from segmentary (or 'tribal') systems, believed

* This is a revised version of the Polish-language paper published in: Banaszkiewicz, Kara, Mamzer (eds) 2015, 303-316. The paper uses data obtained in the course of the research project no. $11 \mathrm{H} 13021682$ implemented between 2014 and 2020, entitled Uściślenie $i$ weryfikacja chronologii oraz periodyzacji grodów tzw. centralnych monarchii pierwszych Piastów (Gniezno, Poznań, Giecz) na podstawie akceleratorowych datowan radioweglowych (The specification and verification of chronology and the periodization of the 'central'strongholds in the monarchy by some archaeologists and historians (following cultural anthropology) to have functioned in the region (e.g., Tymowski 1985; 1999; 2007; 2008; 2009; Lübke 1997; Modzelewski 2004; Kurnatowska

of the first Piasts [Gniezno, Poznań, Giecz] based on accelerated radiocarbon dating). The project was selected in a competition conducted by the Minister of Science and Higher Education of the Republic of Poland and accepted for funding under the research module 1.1 of the National Programme for the Development of Humanities (hereinafter NPRH). The project has been implemented at the Institute of Archaeology and Ethnology of the Polish Academy of Sciences (head: Prof. Michał Kara). 
$2005)^{1}$, to more or less centralized state organisms. This intensification of research into state formation issues has impelled (mostly archaeologists) to re-examine the origins of the Piast regnum ${ }^{2}$, the nucleus of the Kingdom of Poland (Leciejewicz 2000; Kurnatowska 2002; 2008; Moździoch 2002; 2011; 2013; Urbańczyk 2008; 2012; Kara 2009; 2010). Until recently these issues were a minority pursuit within medieval archaeology, whose research questions were heavily related to historical research on the Middle Ages.

\section{The origins of the Polish state as explored by the history of the Middle Ages, notably in the era of 'millennium' research. Major research paradigms}

The process of the gradual formation of the state by the Polanie tribe (the Polans) under the reign of the Piast dynasty was reconstructed both

1 According to M. Sahlins, cultural anthropologists are particularly devoted to investigating segmentary systems (i.e., power segmentation), as such a system pertains to societies representing a certain level of social integration (cf. Vorbrich 2012, 129 and the references cited therein). This view is openly evolutionary, given that a segmentary system is believed to prevail only in tribal societies practicing a simple 'Neolithic' mode of production, mostly within small tribal segments that tend to be largely politically and economically autonomous, this being non-existent in such social systems as a band or chiefdom. This is not the sole definition of a segmentary system referred to in recent subject literature. In his studies on pre-colonial African societies, M. Tymowski (see above) seems to apply the aforementioned designation to pre-state communities, both egalitarian and already distinctly stratified, including those moderated by charismatic individuals from privileged lineage. These communities can form larger, usually poorly integrated spatial systems, bonded by various factors, such as political, military, economic and/or ideological and religious. The term is used in this paper in such an 'unscholastic' sense (Kara 2009).

2 I understand the term regnum as a realm: a more or less firmly established socio-territorial organism, in which community/territory is ruled, at least by definition, by a sovereign (cf. Pohl 2006; 2009). Synonymous with the term regnum (as regards the region of early medieval central and northern Europe) is the term state, i.e., a political organism in the type of a centralized, patrimonial, military monarchy. A monarchy begins to function when a community irrevocably begins to identify the territorial-political organism it forms with a particular, sovereign ruling family (a dynasty). by pre- and post-war historians of the Middle Ages exclusively or primarily on the basis of analyses of available written sources from the period. These narratives are constructed on the basis of historiographical facts, arranged in logical sequences, e.g., with the use of the retrospective method. It appears that some researchers tend to treat the information provided by such sources as data furnishing a virtually complete, although not always reliable or unambiguous account of the past, regardless of the incomplete state of its preservation.

The findings of Polish historian-medievalists concerning the origins of the Piast monarchy have been based upon a number of paradigms, some of which were developed independently by post-war historiography, notably in the era of 'millennium research' (1948/1949-1965/1970); others were inherited from preceding generations:

1. The substrate of the Polish state was comprised of tribal societies, regarded by medievalists as the substance of the state. A tribe, or a macrotribal union that broke up the monopoly of the traditional system based on the identity of the ruler and the people, the Polanie are generally acknowledged to have been the builders of the Piast monarchy. The newly formed state was called Polenia, Polonia, a name coined from their tribal designation (Gieysztor 1970b; cf. Labuda 2002, 26-34; Pleszczyński 2008, 138-148). As regards their territory, Polanie are believed to have lived in present-day Wielkopolska (Great Poland) (Fig. 1). It is thought that they came from the area marked by the strongholds in Giecz, Gniezno, and Poznań, demarcated from the west and the south by the central section of the Warta river, from the north by its right tributary - the Welna river, and from the east by the Maskawa (Moskawa) river, which also flows into the Warta (Gieysztor 1970a). With at least six separate stronghold-settlement clusters in the area of the presentday Wielkopolska, along with Pałuki, Kujawy, Krajna, and the borderland of Wielkopolska and Ziemia Lubuska attributed to their tribal organization, the Polanie were not a spatially uniform formation. In this context, only the Gniezno Land with its direct hinterlands, sometimes extended to the Ląd Land and the Kalisz Land, are regarded as their strict homeland, while other territories are considered to have been incorporated into their state as a result of their expansion (see Zajączkowski 2002 and his overview of hypotheses; cf. Lowmiański 1973, 406-441). 


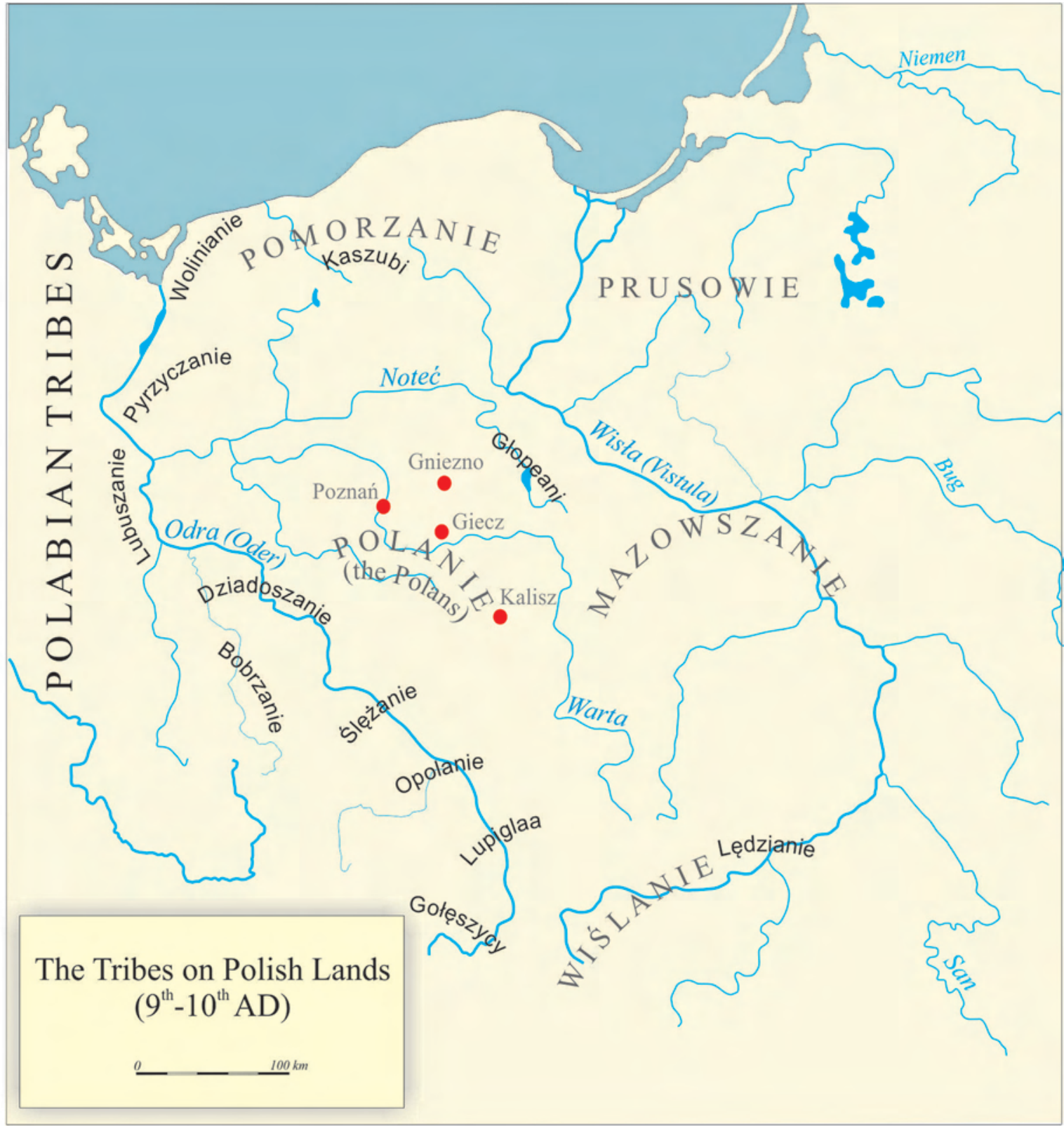

Fig. 1. Map showing location of the $9^{\text {th }} / 10^{\text {th }}$-century tribes on Polish lands according to the findings of researchers from the millennium era. According to Gieysztor 1970b, Fig. 73; redrawn and digitalized by J. Sawicka

2. The formation of the Polish state was a longterm evolutionary process preceded by an initial period with several proto-or early state organisms, called tribal states or territorial-tribal states. It is believed that they were formed in the mid- $9^{\text {th }}$ century at the latest. H. Łowmiański (1976) was the only scholar to reject the hypothesis of the occurrence of proto-state formations in the process of the formation of the Polish state. Łowmiański was nevertheless a strong proponent of the evolutionary nature of the process, the origins of which he saw in the macro-tribal substrate, as well as an advocate of the hypothesis that the formation of the state proceeded from the civilization and cultural breakthrough that consisted in the replacement of the traditional tribal system by a centralized system in which the community/territory was ruled by a sovereign. Incapable of furnishing precise dating of this transformation, Łowmiański suggested only a terminus post quem of the reception of the state model by the Polanie, which he surmised happened around the year 875, when 'Svatopluk (from the House of Mojmir - M.K.) extended his expansion to the Moravian Gate. The inhibition of Svatopluk's expansion into 
Śląsk (Silesia) ca. 884 suggests that the Polanie had already been going through the process of state unification' (Łowmiański 1976, 93-94, in translation). The arguments presented by $\mathrm{H}$. Łowmiański are hence conjectural.

3. Evolutionary explanations of the process of state formation gave rise to another important view of post-war historians of the Middle Ages, who found inspiration in the Marxist theory of historical process. According to this body of thought, states were formed in the course of a long-term, multistep process that occurred within a particular tribal community through evolutionary transformations. This process, called the state formation process or organizational-state process, is deemed to have been a spontaneous and creative social phenomenon, prompted by a combination of definite, mutually antagonistic socio-economic transformations, which also determine its development. In this strand of thinking, the formation of a state is argued to be the result, not the premise of the demographic and socio-economic development of a tribe. The latter factors make up the feudalization processes, understood by the Polish historical studies on the Middle Ages (recent research included) as a socioeconomic stratification synonymous with the development of new social dependencies, progressing in the Odra (Oder) and Vistula river basins from the $8^{\text {th }} / 9^{\text {th }}-9^{\text {th }}$ century and entailing the formation of a class of producers (principally the peasantry) and the ruling class, i.e., a duke along with his retinue (družina) and a group of nobility subordinate to him, who formed the apparatus of the territorial administration of the state (see Gieysztor 1954; Łowmiański $2002 b$ ). The adaptation of a cut-and-dried organizational model of a state by tribal communities which were poised to do it, ergo had an aristocracy and a ruling dynasty capable of managing the process of forming the state, could have performed a pivotal role in the finalization of the state formation process (e.g., Łowmiański 1973; 1976).

4. Unlike Rus' in the $9^{\text {th }}$ century, the Polish state was neither formed owing to an external conquest, nor was it organized by a foreign, for example, Scandinavian aristocratic lineage (see Serejski 1953; Łowmiański 1957; cf. also Wierzbicki 2011). For medievalists, the indigenous origin of the $\mathrm{Pi}$ ast dynasty and their connection with Wielkopolska (notably with the stronghold in Gniezno) are accomplished facts and have never been a matter of debate (c.f. e.g., Łowmiański 2002a). It has been generally acknowledged that under the sway of the Piast dynasty residing in Gniezno, the tribes inhabiting the present-day Wielkopolska, Ziemia Lubuska, Pałuki, Kujawy, Krajna, left-bank Mazovia (i.e., mainly the territories of Central Poland), the Sandomierz Land and at least part of the Chełmno Land, first re-formed their polity into the Gniezno state, i.e., the Piast domain, and then territories of other so-called eastern Lechitic tribes were united into the state subordinate to the Polanie tribe, with its capital in Gniezno. This was effectuated by political methods or subjugation (see Gieysztor 1954; Łowmiański 1976, see also Labuda 1989; more wide-ranging subjugation is posited by e.g., Trawkowski 1962; 1968). By the end of the $10^{\text {th }}$ century, the Piast state was primarily held together by ideological and political relations along with economic ties; it was only the reign of Boleslaw the Brave that transformed the polity into a unified military, administrative, and economic organism, with the region of present-day Wielkopolska (originally the Older Poland) and the region of Małopolska (Little Poland, originally Younger Poland) surrounded by provinces at its core, and became commonly and permanently recognizable among its neighbours under the name of Palania, Polenia, Polonia. It is argued by some historianmedievalists (e.g., Tymieniecki 1961; Łowmiański 1976) that the effectiveness of the organizationalstate process in the area of present-day Wielkopolska was determined by its secluded location, specifically the considerable distance from the Ottonian Empire and Bohemia of the Přemyslids who could have impeded the integration of the 'east Lechitic' tribes by the Polanie tribe for political reasons (some historians propounded also the significance of the remoteness of Wielkopolska from Pomerania, raided by Vikings). The perturbations (attributed to the political activities of the Czech Přemyslids) regarding the spontaneous organizational-state process in the Kraków Land (Craccoa), identified with the territory or part of the territory of the Vistulans, were pointed out to corroborate the hypothesis. Furthermore, the connection of Wielkopolska with the Vistula and the Odra river basins, i.e., the trans-regional communication and trade routes, is believed to have facilitated the instigation of the state formation process in Wielkopolska, notwithstanding its seemingly secluded location. It was speculated that along with luxury goods, also foreign civilization and cultural patterns came to the region upon the War- 
ta river along these routes (e.g., Gieysztor 1954; Tymieniecki 1961; Łowmiański 1973).

5. The inception of the Piast state instigated the process of the formation of the Polish nation in the $11^{\text {th }}-13^{\text {th }}$ centuries (Tymieniecki 1961; Łowmiański 1985; Labuda 2002).

\section{The origins of the Piast state in recent views of medieval archaeology}

The ideas discussed hereunder were formulated throughout the past 20 years in three research centres: in Poznań - in the works of Z. Kurnatowska $(2002 ; 2008)$ and M. Kara (2004; 2009; 2010; 2014; 2018), in Warsaw - in the works of E. Kowalczyk (2000), A. Buko (2005; 2012; 2013) and P. Urbańczyk (2008; 2012; 2015; 2017), and in Wroclaw - e.g., in the works of S. Moździoch $(2002 ; 2011 ; 2013)$. Despite the major impact that the findings of historical ethnology, cultural anthropology, and historical anthropology had on the views of archaeologists (with the exception of E. Kowalczyk), a critical comparison of the foregoing views of 'classical' historian-medievalists with the results of recent archaeological studies on the origins of the Polish state has exhibited a substantial consentience of opinions, at least as regards the research results of archaeologists from Poznan (cf. also Wyrozumski 2003; Banaszkiewicz 2006; Strzelczyk 2013; more careful in this subject is Wiszewski 2013, 175, there is also further critical literature). While differences are noticeable only in two research aspects, the issues are nevertheless of key importance for the subject matter in question.

My research into the periodization of the transformations of settlement-stronghold structures in Wielkopolska, which made use of distinctly procured archaeological, dendrochronological, and radiocarbon analyses, did not confirm the hypothesis of the long-term formation of the oldest monarchy of the Piasts, starting in the so-called tribal age.

Furthermore, those studies repudiated the hypothesis of the extremely evolutionary character of the state formation process in the Warta basin, notably the existence of the tribal proto- or early states, even though in the opinion of Z. Kurnatowska and mine they helped to sustain the very idea of the state formation process of a politico-socio-cultural character, as a general mechanism for the formation of the first Piast monarchy. Nevertheless, unlike 'mil- lennium' scholars, we were of the opinion that this process had not been founded on the evolutionary accumulation of, inter alia, economic factors. The demographic, economic, and cultural development of Wielkopolska, as reflected in archaeological sources dated to the second half of the $10^{\text {th }}$ century onwards, notably in the Gniezno Land, is a derivative, not a prerequisite for the formation of central structures of the Piast state in the area.

The commencement of the organizational-state process would not have been possible if it had not been for the participation of a stratified community of a significant demographic potential. Secondly, it was conditioned by a particular surplus of economic production (particularly food), which could have been allocated for maintaining the duke's družina and the bureaucratic apparatus of the domain, as well as for external exchange. These conditions were optimally fulfilled by an agrarian community, connected by prescription with a particular territory, and internally stratified.

The representatives of the Poznan and Warsaw centres propounded in concert that the state formation process was a sudden cultural and civilizational breakthrough with ensuing consequences soon evident throughout the decades to follow. This suggests the essential role of a prominent family (of a chiefdom structure), equipped with specific charisma, in the formation of the state in its embryo stages. The research results corroborate therefore the prevailing view of the outstanding (though not exclusive) role of the Piast dynasty in the rise of the Polish state, as vividly reflected in the dynastic legend written by Gallus Anonymous in Kronika polska (Gesta Principum Polonorum. The Deeds of the Princes of the Poles, I.1-3).

The analysis of archaeological sources furnishes information regarding the accumulation of real power by the Piasts and its consolidation in this lineage.

In contrast to some archaeologists from the Warsaw and Wroclaw centres (as explained hereunder), Z. Kurnatowska and the author of this paper (2010) believed that within the primary domain, the accumulation and consolidation of power had not been accomplished by internal subjugation, although in certain situations military coercion could have been at play. The hierarchical family of the Piasts performed an essential role in the genesis of the new socio-civilizational order. Having drawn upon social concord or violence (military pressure) and 


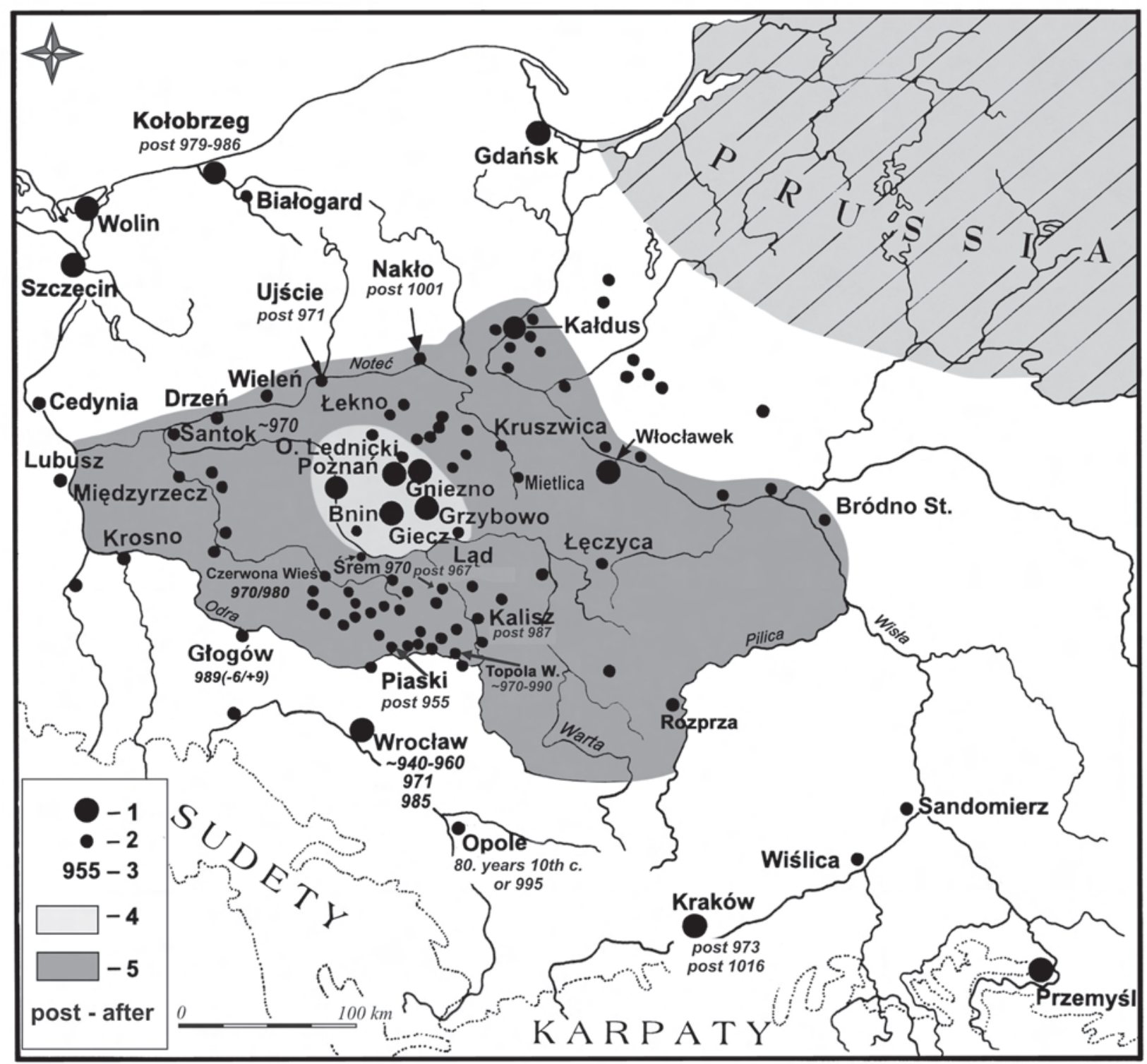

Fig 2. The state of Mieszko I (circa 960-992). According to Z. Kurnatowska and M. Kara (Kara 2009, Fig. 88, with modifications). Redrawn and digitalized by J. Sawicka

Legend: $\mathbf{1}$ - central strongholds in the Gniezno Land and other key Piast strongholds; $\mathbf{2}$ - strongholds of lower-level state administration; 3 - dendro-dates (in Anno Domini) showing when a stronghold was erected or remodeled; 4 - the area spanned by the primary Piast domain (Gniezno Land and its periphery); $\mathbf{5}$ - extent of the civitas Schinesghe in the late $10^{\text {th }}$ century (the western part of present-day Ziemia Lubuska was probably incorporated into the Piast state ca. late $10^{\text {th }} /$ early $11^{\text {th }}$ century)

deftly having taken an advantage of the threat that nearby (communities in the Obra basin?) or remote neighbours (Veleti tribes, the Ottonian Empire) ${ }^{3}$, or competitors in the stage trans-regional trade posed to local communities, in the first half of the $10^{\text {th }}$

3 For an account of the subject see M. Kara 2009, 203-252, 282-290, and the substantiation of the views presented herein. century, they built a stable, coherently fortified domain within the Gniezno Upland and in the eastern part of the Poznan Upland - the nucleus of civitas Schinesghe, i.e., the future Poland (Fig. 2). In return for relinquishing certain prerogatives of power to the Piast dynasty, the communities inhabiting this relatively small area (encompassing approximately $5000 \mathrm{~km}^{2}$ ), were guaranteed effective ritual, social, economic, political, and military peace, and the 
Piasts received a remuneration for their ministrations (this phenomenon applies not only to the Piast dynasty, but also its clientele). The territorialstronghold organization of this power domain was structured around a group comprising at least four of the central strongholds: Gniezno, Poznań, Giecz, and Ostrów Lednicki. Giecz and Ostrów Lednicki seem to have been private residential-sacral Piast centres, unlike Poznań and Gniezno, which were rather important fortified settlements of the community ruled by the Piast dynasty (Kara 2009; Michałowski 2010; Krysztofiak 2016). In this group, Gniezno filled the role of the ideological (ideological and cult) role. Built in the 860s on an earlier settlement (Krąpiec, Krysztofiak 2003; Krysztofiak 2007; 2009; 2016), the stronghold in Giecz is the oldest (or one of the oldest) early medieval strongholds in Central Wielkopolska. As such, the Giecz stronghold is older than the strongholds in Gniezno and Poznań, which were erected as late as in the first half of the $10^{\text {th }}$ century (Kurnatowska 2002, 6082; Kara 2009, 282-316; 2016, 100-108) (Fig. 3) .

4 Not all early medieval strongholds from the area of central Wielkopolska are recognized archaeologically in the extent equal to the Giecz stronghold - hence the above reservation regarding the chronology of the Giecz stronghold.

It cannot be ruled out that the oldest stronghold on Ostrów Tumski in Poznań existed already in the $9^{\text {th }}$ century, although there is no more reliable evidence for that. The verification of the current chronology of the stronghold is supported by calibrated C14 dating of archaeological samples from a complex of pits conducted using the accelerator method at the Poznan Radiocarbon Laboratory as part of the above-mentioned NPRH research project. The pits (the remains of some structures dug in the ground) are part of the oldest stratigraphic and functional system, partly directly overlying the undisturbed subsoil and partly violating its structure, uncovered in the basement of the present episcopal cathedral and identified as cultural layer no. VI with pits. The aforementioned layer together with the overlying cultural layer no. $\mathrm{V}$, within which relics of wooden framework buildings with a probably residential function were found, constituted the foundation of two further Christian temples (a church with a baptistery and a later pre-Romanesque basilica in the Ottonian type), which were built in this location in the second half of the $10^{\text {th }}$ century (characteristics of the sources: Pieczyński 1962, 250-288 [layers IV-VI]; Józefowiczówna 1963, 33-36, 123-227 [layers IV-VI]; results of the reanalysis of sources: Kóčka-Krenz, Kara, Makowiecki 2004, 131-144; Kurnatowska, Kara 2004; Kara 2009, 229, footnote 1291, 245, footnote 1324, 253-282).

The following absolute dates was obtained for layer no. VI:
According to the information contained in the first Polish chronicle written in the early $12^{\text {th }}$ century by

pit no. 1: sample no. P-Kat. 1954-10 (lab. no. Poz-71230, bone prong, depth minus $4.1 \mathrm{~m}$ ) - C14 date: 1210+/-30 BP, probabilistic intervals of the calibrated calendar age with measurement probability and confidence levels: cal. AD $771-780$ (68.2\% / 6.3\%), 788-875 (68.2\% / 61.9\%), 695-700 (95.4\% / 0.6\%), 710-745 (95.4\% / 10.8\%), 764-891 (95.4\% / 83.9\%);

pit no. 1: sample no. P-Kat. 1954-11 (lab. no. Poz-71231, antler prong, depth minus $4.12 \mathrm{~m}$ ) - C14 date: 1175+/-30 BP, probabilistic intervals of the calibrated calendar age with measurement probability and confidence levels: cal. AD 777-793 (68.2\% / 11.1 \%), 801-890 (68.2\% / 57.1\%), 770-902 (95.4\% / 84.4\%), 919-963 (95.4\% / $11.0 \%)$

pit no. 2: sample no. P-Kat. 1954-21 (lab. no. Poz-81472, tar fragment from a tar vessel, depth minus $4.1 \mathrm{~m}$ ) - C14 date: $1200+/-30 \mathrm{BP}$, probabilistic intervals of the calibrated calendar age with measurement probability and confidence levels: cal. AD $775-779$ (68.2\% / 3.4\%), $788-873$ (68.2\% / 64.8\%), 715-744 (95.4\% / 6.2\%), 765-895 (95.4\% / 87.8\%), 928-940 (95.4\% / 1.4\%).

The radiocarbon dates are not in conflict with the results of the chronological analysis of artefacts (including pottery assemblages) from layer VI and associated pits, which are typical for phase $\mathrm{D}_{0}$ (for the characteristics of the phase see Kara 2000; 2009; 2016). Judging from the dating of similar sets of vessels recovered from undisturbed layers of richly fortified settlements of northern Polabia (mainly the Veletian part) and Western Pomerania (see Kara 2009, 229 , footnote $1291,255,257$, footnote 1374 , and the references cited therein; Łosiński 2008, 107-108, Table 1 [types G-J]), in the case of Poznań, there are premises for extending the lower limit of the approximate age range of ceramic assemblages from layer VI to the end of the $9^{\text {th }}$, possibly the turn of the $10^{\text {th }}$ century. We should add that the upper ceiling of the interval should be placed in the first half of the $10^{\text {th }}$ century, this time in accordance with the chronology of the $\mathrm{D}_{0}$ phase proposed in the literature (about 900-950/960). We can therefore circumspectly date the beginnings of the deposition of the 'Poznań' layer no. VI to this time, bearing in mind that the sedimentation processes took place also in the early $10^{\text {th }}$ century, a conclusion which results from the stratigraphic analysis of the studied settlement relics. Pottery assemblages recovered from layer no. V, which directly overlaid layer no. VI, are typical for phase $\mathrm{D}_{0}$. Due to the lack of direct spatial relations, which would clearly indicate the relationship between the radiocarbon dating of pits from layer no. VI and the remains of the wooden-earth ramparts of the stronghold discovered at the site, including the relics of the oldest (?) phase of the fortifications, it is not possible to determine whether the pits were related to the horizon of anthropogenic activities preceding the construction of the stronghold centre on Ostrów Tumski in Poznań, or already with the primary phase 
Gallus Anonymous (I.8) (see above), together with the stronghold in Włocławek (Wladislau) in eastern Kujawy, the strongholds formed the group of the main or central strongholds of Bolesław the Brave (who ruled between 992 and 1025). They ensured his military power, lending a real dimension to his authority, while raising his prestige also in the region $^{5}$. In this context, let us note the concept of A. Buko $(2000 ; 2005 ; 2012 ; 2013)$, who repudiates the above interpretation of the centres of the oldest Piast monarchy and insists that it was the Kalisz

of the stronghold. Two oak wood samples (Quercus sp.) retrieved from the charred, poorly preserved outer part of the ramparts were dendrochronologically dated by M. Krąpiec (Absolute Dating Laboratory in Cianowice/Kraków): after 897 AD and after 936 AD, respectively (Kóčka-Krenz, Kara, Makowiecki 2004, 134, Fig. 7 [dendro-dates: no. 1]).

While it is widely accepted that the Poznan stronghold functioned in the first half of the $10^{\text {th }}$ century, the hypothesis that it was established in the $9^{\text {th }}$ century (see Kóčka-Krenz 2008) remains open but not unlikely.

5 Włocławek could have been included in the aforementioned structure of strongholds as late as in the second Piast state. There was even a supposition (Bieniak 1963, 30, footnote 21) that as a result of a copyist error, it is Ostrów Lednicki instead of Włocławek that should have been mentioned in the verse of the Polish Chronicle of Gallus Anonymous, which is, nevertheless, unlikely (for more recent findings regarding the early Piast stronghold in Włocławek, see Banaszkiewicz 2016; Michałowski 2016).
Land with the stronghold in Kalisz-Zawodzie that was the primary seat of the family, even though written sources remain silent in this regard ${ }^{6}$.

According to the researchers from Poznan, the effectiveness of the 'Piast' organizational experiment lay not only in the determination in the adaptation of new cultural and civilizational patterns of the then social elite (in terms of militarized, noble families centred around leaders with judicial-military-ritual prerogatives - cf. Samsonowicz 2006), but also, and possibly imprimis, in the consolidation of the local agrarian communities, i.e., indigenous people, around the charismatic Piast dynasty, which was perhaps favoured by social agreements. Thus, the $10^{\text {th }}$ century brought the formation of the socio-political organism of the Polanie tribe in lieu of the hitherto prevailing tribal community. Highly significant for this case was the appropriation of the 'old', pre-state centres of cult and power (e.g., in Gniezno) by the Piasts, as well as the effective implementation of the regnum model, i.e., the early state (realm), identical to the deployment of a system, in which a community/territory is ruled by a sovereign (e.g., in the Bohemia of the Přemyslids), as pointed out by the historian H. Lowmiański (1976).

6 For the critical discussion with A. Buko's ideas, see Kurnatowska, Kara 2010, 42, footnote 62; Kara 2014.

On next page:

Fig. 3. Strongholds and alleged ritual-cult sites from phase $C$ (end of the $9^{\text {th }} /$ first half of the $10^{\text {th }}$ century) and phase $D_{0}$ (first half of the $10^{\text {th }}$ /beginning of the second half of the $10^{\text {th }}$ century) along with the earliest in the Warta river basin hoards of hacksilver against archaeologically determined extent of the earliest Piast domain (first half of the $10^{\text {th }}$ /beginning of the second half of the $10^{\text {th }}$ century), extent of areas politically related to the domain (the 'collaboration' zone) and extent of areas subjugated by the Piasts ca. mid- $10^{\text {th }}$ century at the latest. According to Kara 2009, Fig. 86; drawn by

M. Śniedziewska-Lerczak and J. Sawicka

Legend: 1 - stronghold functioning after 950, erected in the earlier phases of the Early Middle Ages; 2 - stronghold functioning after 950 , erected in the late $9^{\text {th }}$ or early $10^{\text {th }}$ century; 3 - stronghold which ceased to function ca. mid- $10^{\text {th }}$ century at the latest, erected in the earlier phases of the Early Middle Ages; $\mathbf{4}$ - stronghold from the late $9^{\text {th }}-$ first half of the $10^{\text {th }}$ century or from the first half (basically the second quarter) of the $10^{\text {th }}$ - the beginning of the second half of the $10^{\text {th }}$ century (the latter only within central Wielkopolska [Great Poland], most notably the Gniezno Upland); 5 - stronghold which ceased to function in the late $10^{\text {th }}$ early $11^{\text {th }}$ century at the latest, erected in the earlier phases of the Early Middle Ages; 6 - stronghold which ceased to function in the late $10^{\text {th }} /$ early $11^{\text {th }}$ century at the latest, erected in the late $9^{\text {th }}$ or in the early $10^{\text {th }}$ century; 7 - chronology uncertain; 8 - alleged ritual-cult site; $\mathbf{9}$ - as above, but chronology uncertain; 10 - hoard of dirhams with a date of deposition; 11 - alleged sacred mountain with a historical or present proper name; 12 - extent of the oldest Piast patrimonial domain along with the Poznań segment incorporated into the domain in the early $10^{\text {th }}$ century (hatched area); 13 - the zone of the collaboration with the Piast realm (areas incorporated by the Piasts ca. mid- $10^{\text {th }}$ century at the latest); 14 - as above, but incorporation not earlier than ca. $10^{\text {th }} / 11^{\text {th }}$ century; 15 - the zone of the Piast conquests (areas incorporated ca. mid-10 ${ }^{\text {th }}$ century at the latest); 16 - the Gniezno configuration (chain) of strongholds dated to $\mathrm{D}_{0}$ phase (in this group only Giecz was erected in the $9^{\text {th }}$ century) 


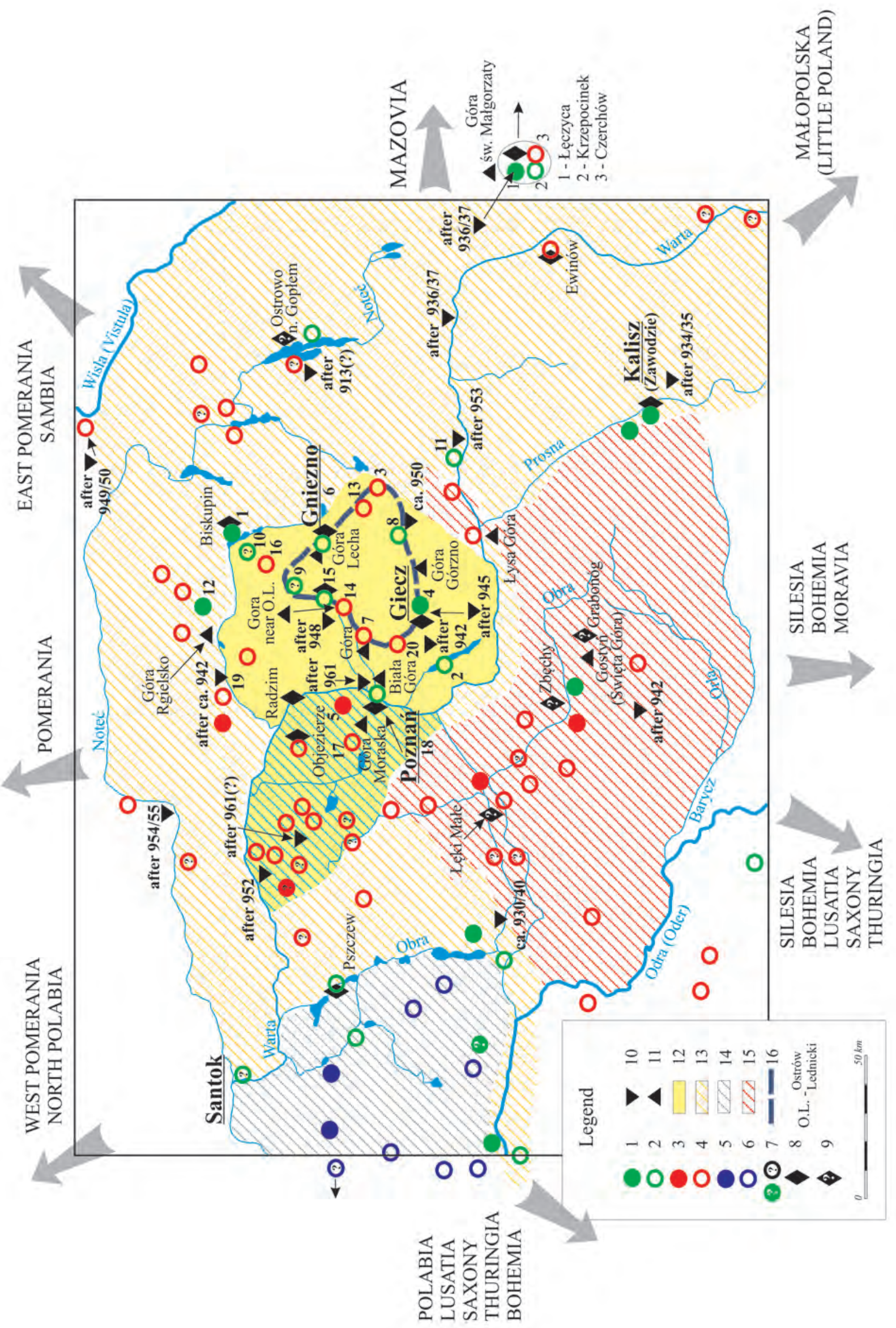


We believe that the remoteness of the territory of the established domain from the borders of its imperial neighbour, in this case the Ottonian Empire, was also of considerable significance, since the empire was thus deprived of the possibility to directly participate in the local political game. This condition was strongly emphasized in the work of medievalists of the 'millennium' era, who deemed it one of the major premises of the effectiveness of the state formation process in the Warta river basin. Note that the empire might be interested in the political rise of the Piast dynasty in the region. Having professed similar ideological values and forming a political alliance with the empire (in amititium), the Piasts may be said to have stabilized the political situation in the eastern foreland of the empire on its behalf.

The Piasts continued to extend the boundaries of their primary domain in many directions by pursuing territorial conquest, thus subjugating neighbouring communities e.g., from the upper and middle Obra river basin. In turn, in the 'collaboration' zones (Pałuki, Kujawy, the eastern part of Ziemia Lubuska, selected enclaves of the Sieradz-Łęczyca Land, the Kalisz Upland) non-military methods, e.g., pressure, machinations, or political agreements, were preferably employed. Matrimonial relationships with the Piast dynasty might have been of relevance in the case of these territories (Kara 2009, 249ff) (Fig. 3). Thus, the state so established, along with its pertinences - the name of which from the times of Boleslaw the Brave was identified not only with Gniezno (the symbolic capital of that organism), but also with a particular political society (Polenia/Polonia) - constituted the nucleus of the present-day Poland, despite certain territorial instability.

Archaeologists A. Buko (2005; 2012; 2013), S. Moździoch $(2011 ; 2013)$, and for some time also P. Urbańczyk $(2008)^{7}$ advanced a slightly different view of the mechanism of the formation of the Piast monarchy. They argue that the earliest Piast regnum was formed ad hoc by conquest and repudiate the foregoing idea of the significance of social agreements supported in certain cases by military pressure postulated by the researchers opting for a modified variant of the state formation process in the genesis of the realm, a socio-political forma-

In his 2012 book P. Urbańczyk presents a revised version of his previous ideas. tion of the early state type (e.g., Z. Kurnatowska, M. Kara $)^{8}$.

In his 2008 book, P. Urbańczyk, then closely followed by S. Moździoch, equated the oldest Piast regnum with the strong position of the chief - a military leader. He expounded the idea that the community subordinated to the leader did not form a state, i.e., a constitutional and legal spatial order in the form of an internally hierarchical and strictly centralized structure based on functionally diversified and territorially stable settlement-stronghold systems. Instead, Urbańczyk argued, the community produced a territorially and politically unstable formation that was likewise inconsistent as regards economy and culture. It was a kind of a conglomerate of local communities, subordinated in a relatively short period of time by military coercion to the political power or supremacy of the chief. Only did the emergence of a dynasty guarantee the gradual transformation of the regnum (realm) into a hereditary monarchy, which became a state once the borders were stable, a legal system was adopted, and a politically integrated society developed. To conclude, according to these researchers, the oldest Piast regnum did not originate as a result of an intense, although fairly brief socio-cultural and political process occurring in the Gniezno Land with the prominent participation of ambitious and charismatic leaders (probably typically from chieftain lineages), employing, depending on the circumstances, either a social contract or military pressure in political activities (vide the Piasts), in which the Poznań archaeologists see the causation of the emergence of the earliest territorial realm of the family. P. Urbańczyk elucidates that the regnum of the Piasts was formed by the spontaneous political and military actions of the dynasty in a favourable regional political situation. Neither did the Piasts eschew internal conquest (the foregoing view is shared particularly by S. Moździoch; a similar opinion, although carefully worded, is present in the studies of A. Buko). Note that P. Urbańczyk (2008) ruled out the Polanie tribe - deemed by historians as the subject of the state formation process - from the list of entities recognized by history.

Notwithstanding differences regarding the substance and scope of the methods employed by the Piasts in their state formation political game, and

8 For the idea of the early state see Claessen, Skalník (eds) 1978; Tymowski 2015. 
even concerning the location of the area of the primary political activity of the ruling dynasty, archaeologists' opinions are similar in essence and share a great deal of common ground: the earliest Piast monarchy did not form in the course of a long-term and spontaneous evolutionary processes, neither did it bear a resemblance to political structures referred to in the literature as 'gens', 'ethnic group' or 'chiefdom'. Not an ephemeral entity, it was capable of further development under the reign of its own rulers. The important role of a prominent, charismatic family (with eligibilities of chiefs) is hence implied in the formation of the state in its embryonic stages and research findings corroborate the idea, prevalent in scholarship, of the essential (though not exclusive) role of the Piast dynasty in the Polish state formation, as notably reflected in the dynastic legend recorded by Gallus Anonymous in his Kronika polska (Gesta Principum Polonorum. The Deeds of the Princes of the Poles, I.1-3). Importantly, the emergence of the first Piast monarchy was not tantamount to the formation of the Polish nation as a specific ethno-socio-political unity, the consolidation of which occurred much later.

To conclude, it is noteworthy that the images of the past reconstructed within autonomous analyses of historiography and archaeology can be divergent in many respects due to the discrepancy between the nature of the sources, research procedures, and last but not least, the theories adopted by the disciplines (cf. Rębkowski 2008; Kurnatowska, Kurnatowski 2012; Kowalczyk-Heyman 2018). It is worth mentioning in this context that the research undertaken by medieval archaeology focuses primarily on questions related to socio-cultural changes in the geographical and natural landscape, while the subject matter of historical research on the Middle Ages (at least in its classic approach) is dominated by source studies, socio-economic, constitutional and legal issues, as well as an interest in political events.

It should also be noted that the adoption of Christianity by Mieszko I in 966 initiated the process of the Christianization of the community under his authority, thus opening new civilizational and cultural prospects for both his court and the broader community (Steele 2020). Although this ultimately decided the inclusion of Poland into the circle of the Latin civilization, it was not a sine qua non condition for the formation of the early Piast state. The Christianization of the state, however, determined its permanence and political advancement in the region.

Translated by Agnieszka Tokarczuk

\section{BIBLIOGRAPHY}

\section{Sources:}

Gallus Anonymous - Anonim tzw. Gall, Kronika polska. 1982. Translated by R. Grodecki, with a preface and editorial corrections by M. Plezia. Wrocław5: Zakład Narodowy imienia Ossolińskich - Wydawnictwo (= English translation: Gesta principum Polonorum. The Deeds of the Princes of the Poles. 2003. Translated and annotated by P.W. Knoll and F. Schaer, with a preface by T.N. Bisson and with editorial corrections. Budapest - New York: Central European University Press).

\section{References:}

Banaszkiewicz J. (2006). History and archaeology - together or separate? Some remarks by a Medieval histo- rian on the uses and misuses of history by archaeologists. Archaeologia Polona, 44, 195-201.

Banaszkiewicz J. (2016). Giecz na Gallowej liście wielkich grodów Bolesława Chrobrego. In: M. Kara, T. Krysztofiak, A.M. Wyrwa (eds), Gród piastowski w Gieczu. Geneza - funkcja - kontekst (75-90). Poznań: Instytut Archeologii i Etnologii PAN \& Poznańskie Towarzystwo Przyjaciół Nauk.

Banaszkiewicz J., Kara M., Mamzer H. (eds) 2015. Instytucja 'wczesnego państwa' w perspektywie wielości i różnorodności kultur. Poznań: Instytut Archeologii i Etnologii Polskiej Akademii Nauk, edition 2.

Bieniak J. (1963). Rola Kujaw w Polsce Piastowskiej. Ziemia Kujawska, 1, 27-71.

Buko A. (2000). Małopolska 'czeska' i Małopolska 'polańska'. In: H. Samsonowicz (ed.), Ziemie polskie $w X$ wieku $i$ ich znaczenie $w$ ksztaltowaniu się nowej 
mapy Europy (143-168). Kraków: Towarzystwo Autorów i Wydawców Prac Naukowych UNIVERSITAS.

Buko A. (2005). Archeologia Polski wczesnośredniowiecznej. Odkrycia - hipotezy - interpretacje. Warszawa: Wydawnictwo TRIO.

Buko A. (2012). Ośrodki centralne a problem najstarszego patrymonium dynastii Piastów. Archeologia Polski, 57(1-2), 133-159.

Buko A. (2013). Old ties, new challenges. The power centres and the rise of the oldest Piast's patrimony in archaeological perspective. In: S. Moździoch, P. Wiszewski (eds), Consensus or Violence? Cohesive Forces in Early and High Medieval Societies (9th-14th c.) (67-81). Wrocław: Institute of History at the University of Wroclaw \& Institute of Archaeology and Ethnology of the Polish Academy of Sciences.

Claessen H.J.M., Skalník P. (eds). (1978). The Early State. The Hague: Mouton.

Gieysztor A. (1954). Geneza państwa polskiego w świetle nowszych badań. Kwartalnik Historyczny, 61(1), 103136.

Gieysztor A. (1970a). Polanie. In: G. Labuda, Z. Stieber (eds), Słownik starożytności Słowiańskich (181-182), 4(1). Wrocław: Zakład Narodowy imienia Ossolińskich \& Wydawnictwo Polskiej Akademii Nauk.

Gieysztor A. (1970b). Polska. Nazwa kraju - Podstawy geograficzne - Historia i ustrój polit. - Kultura. In: G. Labuda, Z. Stieber (eds), Słownik starożytności słowiańskich (187-193), 4(1). Wrocław: Zakład Narodowy imienia Ossolińskich \& Wydawnictwo Polskiej Akademii Nauk.

Józefowiczówna K. (1963). Z badańnad architektura przedromańska $i$ romańska $w$ Poznaniu. Polskie badania archeologiczne, 9. Wrocław: Instytut Historii Kultury Materialnej Polskiej Akademii Nauk \& Zakład Narodowy imienia Ossolińskich \& Wydawnictwo Polskiej Akademii Nauk.

Kara M. (2000). Anfänge der Bildung des Piastenstaates im Lichte neuer archäologischer Ermittlungen. Quaestiones Medii Avvi Novae, 5, 57-85.

Kara M. (2004). Archeologia o początkach państwa Piastów (wybrane zagadnienia). In: W. Fałkowski (ed.), Kolory i struktury średniowiecza (253-317). Warszawa: Wydawnictwo DiG.

Kara M. (2009). Najstarsze państwo Piastów - rezultat przełomu czy kontynuacji? Studium archeologiczne. Poznań: Instytut Archeologii i Etnologii Polskiej Akademii Nauk.

Kara M. (2010). Medieval historical studies and medieval archaeology about the origin of the Piast State. An overview. Archaeologia Polona, 48, 2015, 37-58.
Kara M. (2014). The Conquest Involving Viking War-Bands in the Process of the Piast State Formation. A Critique. Slavia Antiqua, 55, 125-143.

Kara M. (2016). Relikty osadnictwa ze starszych faz wczesnego średniowiecza oraz przełomu faz starszych i młodszych (od około VI/VII do pierwszej połowy XI w.) z obszaru obecnej tzw. małej aglomeracji miasta Poznania. Próba zarysu przemian osadniczych według nowszych ustaleń archeologii. In: M. Kara, M. Makohonienko, A. Michałowski, Przemiany osadnictwa i środowiska przyrodniczego Poznania i okolic od schytku starożytności do lokacji miasta (71-132). Ekologia Historyczna Poznania, 1. Poznań: Bogucki Wydawnictwo Naukowe.

Kara M. (2018). Transformations of Elite Culture in Wielkopolska Related to the Process of the Piast State Formation (with a Particular Emphasis on Strongholds). An Archaeological Perspective. In: P. Kouřil, R. Procházka et al., Moravian and Silesian Strongholds of the Tenth and Eleventh Centuries in the Context of Central Europe (307-318). Spisy Archeologického ústavu AV ČR Brno, 57. Brno: The Czech Academy of Sciences, Institute of Archaeology - Brno.

Kowalczyk E. (2000). Momenty geograficzne państwa Bolesława Chrobrego. Na styku historii i archeologii. Kwartalnik Historyczny, 107(2), 41-76.

Kowalczyk-Heyman E. (2018). Archeologia dla historyków, historia dla archeologów, czyli kilka uwag o programie kształcenia mediewistów. In: A. Buko, K. Kollinger, S. Jędrzejewska (eds), Badania interdyscyplinarne (13-21). Materiały V Kongresu Mediewistów Polskich, 4. Rzeszów: Wydawnictwo Uniwersytetu Rzeszowskiego.

Kóčka-Krenz H. (2008). Najstarszy Poznań - wciąż odkrywany. In: T. Sawicki (ed.), Studia nad dawna Polska (35-53), 1. Gniezno: Muzeum Początków Państwa Polskiego.

Kóčka-Krenz H., Kara M., Makowiecki D. (2004). The Beginnings, Development and the Character of the Early Piast Stronghold in Poznań In: P. Urbańczyk (ed.), Polish Lands at the Turn of the First and the Second Millennia (125-166). Warsaw: Institute of Archaeology and Ethnology Polish Academy of Sciences.

Krąpiec M., Krysztofiak T. (2003). Potwierdzenie plemiennej genezy grodu w Gieczu. Wielkopolskie Sprawozdania Archeologiczne, 6, 32-51.

Krysztofiak T. (2007). Rozwój wczesnośredniowiecznego ośrodka grodowego w Gieczu w świetle źródeł archeologicznych. In: A. Grygorowicz, K. Milecka, K. Tobolski (eds), Architektoniczno-przestrzenne $i$ przyrodnicze podstawy rekonstrukcji wczesnośre- 
dniowiecznych założeń obronnych Giecza (15-39). Poznań: Instytut Architektury i Planowania Przestrzennego Wydziału Architektury Politechniki Poznańskiej.

Krysztofiak T. (2009). Giecz. Gródek przedpaństwowy - wczesnopiastowski gród centralny - ośrodek kasztelański. In: A.M. Wyrwa (ed.), Custodia Meomoriae. Muzeum Pierwszych Piastów na Lednicy. XL lat istnienia (1969-2009) (111-139). Lednica: Muzeum Pierwszych Piastów na Lednicy.

Krysztofiak T. (2016). Ośrodek grodowy w Gieczu w okresie przed- $i$ wczesnopaństwowym. In: M. Kara, T. Krysztofiak, A.M. Wyrwa (eds), Gród piastowski w Gieczu. Geneza - funkcja-kontekst (115-154). Poznań: Instytut Archeologii i Etnologii PAN \& Poznańskie Towarzystwo Przyjaciół Nauk.

Kurnatowska Z. (2002). Początki Polski. Mała Biblioteka PTPN, 9. Poznań: Poznańskie Towarzystwo Przyjaciół Nauk.

Kurnatowska Z. (2005). Kraków i ziemia krakowska w procesie formowania się państwowości na ziemiach polskich. In: J. Gadomski, A. Małkiewicz, T. Rodzińska-Chorąży, A. Włodarek (eds), Lapides viventes. Zaginiony Kraków wieków średnich. Księga dedykowana Profesor Klementynie Żurowskiej (21-27). Kraków: Instytut Historii Sztuki Uniwersytetu Jagiellońskiego \& Wydawnictwo Uniwersytetu Jagiellońskiego.

Kurnatowska Z. (2008). Początki i rozwój państwa. In: M. Kobusiewicz (ed.), Pradzieje Wielkopolski. Od epoki kamienia do średniowiecza (297-395). Poznań: Instytut Archeologii i Etnologii Polskiej Akademii Nauk.

Kurnatowska Z., Kara M. (2004). Początki architektury sakralnej na grodzie poznańskim w świetle nowych ustaleń archeologicznych. In: T. Janiak, D. Stryniak (eds), Poczatki architektury monumentalnej w Polsce. Materiały z sesji naukowej Gniezno, 20-21 listopada 2003 roku (47-70). Gniezno: Muzeum Początków Państwa Polskiego.

Kurnatowska Z., Kara M. (2010). Wczesnopiastowskie regnum - jak powstało i jaki miało charakter? Próba spojrzenia od strony źródeł archeologicznych. Slavia Antiqua, 51, 23-96.

Kurnatowska Z., Kurnatowski S. (2012). Parę uwag o odkrywaniu rzeczywistości kulturowej poprzez źródła archeologiczne. In: A. Pleszczyński, J. Sobiesiak, M. Tomaszek, P. Tyszka (eds), Historia Narrat. Studia mediewistyczne ofiarowane Profesorowi Jackowi Banaszkiewiczowi (21-64). Lublin: Wydawnictwo Uniwersytetu Marii Curie-Skłodowskiej.
Labuda G. (1989). Pierwsze państwo polskie. Kraków: Krajowa Agencja Wydawnicza RSW „Prasa-KsiążkaRuch".

Labuda G. (2002). Mieszko I. Wrocław: Zakład Narodowy imienia Ossolińskich - Wydawnictwo.

Leciejewicz L. (2000). Nowa postać świata. Narodziny średniowiecznej cywilizacji europejskiej. Monografie Fundacji na Rzecz Nauki Polskiej. Seria Humanistyczna. Wrocław: Fundacja na Rzecz Nauki Polskiej.

Lübke Ch. (1997). Forms of Political Organisation of the Polabian Slavs (until the 10th Century A.D.). In: P. Urbańczyk (ed.), Origins of Central Europe (115124). Warsaw: Scientific Society of Polish Archaeologists \& Institute of Archaeology and Ethnology Polish Academy of Sciences.

Łosiński W. (2008). Pomorze Zachodnie we wczesnym średniowieczu. Studia archeologiczne. Seria: A. Janeczek (ed.), Collectio archaeologica, historica et ethnologica, 3. Poznań: Instytut Archeologii i Etnologii Polskiej Akademii Nauk.

Łowmiański H. (1957). Zagadnienie roli Normanów w genezie państw stowiańskich. Warszawa: Państwowe Wydawnictwo Naukowe.

Łowmiański H. (1973). Początki Polski. Z dziejów Stowian w I tysiacleciu n.e., 5. Warszawa: Państwowe Wydawnictwo Naukowe.

Łowmiański H. (1976). Problematyka początków państwa polskiego w nowszych badaniach historycznych. Slavia Antiqua, 23, 75-110.

Łowmiański H. (1985). Początki Polski. Polityczne i społeczne procesy ksztattowania się narodu do poczatku wieku XIV, 6 (1-2). Warszawa: Państwowe Wydawnictwo Naukowe.

Łowmiański H. (2002a). Dynastia Piastów we wczesnym średniowieczu. In: K. Tymieniecki, G. Labuda, H. Łowmiański (eds), Początki państwa polskiego. Księga tysiaclecia (111-162), 1. Poznań: Poznańskie Towarzystwo Przyjaciół Nauk, reprint from 1962 edition.

Łowmiański H. (2002b). Zagadnienia gospodarcze wczesnofeudalnego państwa polskiego. In: K. Tymieniecki, G. Labuda, H. Łowmiański (eds), Początki państwa polskiego. Księga tysiąclecia (15-36), 2. Poznań: Poznańskie Towarzystwo Przyjaciół Nauk, reprint from 1962 edition.

Michałowski R. (2010). Pałace monarsze na tle geografii sakralnej pierwszej monarchii piastowskiej. Uwagi wstępne. In: A. Bartoszewicz, G. Myśliwski, J. Pysiak, P. Żmudzki (eds), Świat średniowiecza. Studia ofiarowane Profesorowi Henrykowi Samsonowiczowi (454-467). Warszawa: Instytut Historyczny Uniwer- 
sytetu Warszawskiego \& Wydawnictwo Uniwersytetu Warszawskiego.

Michałowski R. (2016). Kontekst historyczny znaleziska w Bodzi. In: A. Buko (ed.), Bodzia. Elitarny cmentarz z początków państwa polskiego (33-39). Warszawa: Instytut Archeologii i Etnologii Polskiej Akademii Nauk.

Modzelewski K. (2004). Barbarzyńska Europa. Warszawa: Wydawnictwo ISKRY.

Moździoch S. (2002). Castrum munitissimum Bytom. Lokalny ośrodek władzy w państwie wczesnopiastowskim. Warszawa: Wydawnictwo DiG.

Moździoch S. (2011). 'Bodaj się Piastów rządy nam święciły'. Archeologia o początkach państwa piastowskiego. In: M. Rębkowski, S. Rosik (eds), Populi Terrae Marisque. Prace poświęcone pamięci Profesora Lecha Leciejewicza (67-81). Wrocław: Wydawnictwo Chronicon.

Moździoch S. (2013). Consensus or violence? Archaeology and the beginnings of the Piast State. In: S. Moździoch, P. Wiszewski (eds), Consensus or Violence? Cohesive Forces in Early and High Medieval Societies (9th14th c.) (299-314). Wrocław: Institute of History at the University of Wroclaw \& Institute of Archaeology and Ethnology of the Polish Academy of Sciences.

Pieczyński Z. (1962). Materiały z warstw przedsakralnych odsłoniętych w katedrze poznańskiej w latach 19511956. Fontes Archaeologici Posnanienses, 13, 1963, 246-288.

Pleszczyński A. (2008). Niemcy wobec pierwszej monarchii piastowskiej (963-1034). Narodziny stereotypu. Postrzeganie i cywilizacyjna klasyfikacja władców Polski i ich kraju. Lublin: Wydawnictwo Uniwersytetu Marii Curie-Skłodowskiej.

Pohl W. (2006). Staat und Herrschaft in Frühmittelalter. Überlegungen zum Forschungsstand. In: S. Airlie, W. Pohl, H. Reimitz (eds), Staat im frühen Mittelalter (9-38). Wien: Verlag der Österreichischen Akademie der Wissenschaften.

Pohl W. (2009). 'Regnum' und 'gens'. In: W. Pohl, V. Wieser (eds), Der frühmittelalterliche Staat-europäische Perpektiven (435-450). Wien: Verlag der Österreichischen Akademie der Wissenschaften.

Rębkowski M. (2008). Czy archeolog odczytuje historię średniowiecza? Uwagi o znaczeniu źródeł archeologicznych. In: S. Suchodolski (ed.), Źródła historyczne wydobywane z ziemi. II Kongres Mediewistów Polskich Lublin, 19-21 września 2005 roku (11-31). Wrocław: Instytut Archeologii i Etnologii Polskiej Akademii Nauk \& Wydawnictwo Chronicon.
Samsonowicz H. (2006). Dynastia, czyli od społecznej struktury plemiennej do państwowej. In: J. Dobosz (ed.), Przemyślidzi i Piastowie - twórcy i gospodarze średniowiecznych monarchii (15-22). Poznań: Wydawnictwo Poznańskie.

Serejski M. (1953). Z zagadnień genezy państwa polskiego w historiografii (o tzw. teorii podboju). Kwartalnik Historyczny, 60(3), 147-163.

Steele Ph.E. (2020). Homo religiosus: the phenomenon of Poland's Mieszko I. In: I. Kąkolewski, Ch. Lübke, P. Urbańczyk (eds), The Dawning of Christianity in Poland and across Central and Eastern Europe (185217). Berlin: Peter Lang.

Strzelczyk J. (2013). Mieszko I w świetle niektórych nowszych badań. In: P. Migdalski (ed.), Cedynia i okolice poprzez wieki (31-35). Chojna: Stowarzyszenie Historyczno-Kulturalne 'Terra Incognita' \& Instytut Historii i Stosunków Międzynarodowych Uniwersytetu Szczecińskiego.

Trawkowski S. (1962). Jak powstawała Polska. Warszawa: Wiedza Powszechna.

Trawkowski S. (1968). Nad Wisłą i Odrą w VIII i IX wieku. Narodziny państwa polskiego. Monarchia Mieszka I i Bolesława Chrobrego. In: T. Manteuffel (ed.), Polska pierwszych Piastów. Państwo - społeczeństwo - kultura (42-145). Warszawa: Państwowe Wydawnictwo Naukowe.

Tymieniecki K. (1961). Polska w średniowieczu. Warszawa: Państwowe Wydawnictwo Naukowe.

Tymowski M. (1985). Karabin i władza w Afryce XIX wie$k u$. Państwa i armie Samoriego i Kenedugu oraz ich analogie europejskie. Warszawa: Państwowe Wydawnictwo Naukowe.

Tymowski M. (1999). Państwa Afryki przedkolonialnej. Monografie Fundacji na Rzecz Nauki Polskiej. Seria Humanistyczna. Wrocław: Fundacja na Rzecz Nauki Polskiej.

Tymowski M. (2007). Organizacje typu imperialnego w Afryce przedkolonialnej a problem segmentacji władzy. Kwartalnik Historyczny, 114(3), 37-48.

Tymowski M. (2008). State and Tribe in the History of Medieval Europe and Black Africa - a Comparative Approach. Social Evolution \& History, 7(1), 171-196.

Tymowski M. (2009). Tribal organizations in pre-state Poland ( $9^{\text {th }}$ and $10^{\text {th }}$ centuries) in the light of anthropological theories of segmentary system and chiefdom. Acta Poloniae Historica, 99, 5-37.

Tymowski M. (2015). Kilka problemów wynikających z zastosowania teorii Early State do badań przedkolonialnych państw Afryki Czarnej. In: J. Banaszkiewicz, 
M. Kara, H. Mamzer (eds), Instytucja 'wczesnego państwa' $w$ perspektywie wielości i różnorodności kultur (75-89). Poznań: Instytut Archeologii i Etnologii Polskiej Akademii Nauk, edition 2.

Urbańczyk P. (2008). Trudne początki Polski. Monografie Fundacji na Rzecz Nauki Polskiej. Seria Humanistyczna. Wrocław: Fundacja na Rzecz Nauki Polskiej.

Urbańczyk P. (2012). Mieszko Pierwszy tajemniczy. Monografie Fundacji na Rzecz Nauki Polskiej. Seria Humanistyczna. Toruń: Fundacja na Rzecz Nauki Polskiej.

Urbańczyk P. (2015). Zanim Polska została Polska. Toruń: Wydawnictwo Naukowe Uniwersytetu Mikołaja Kopernika.

Urbańczyk P. (2017). Bolesław Chrobry - lew ryczacy. Monografie Fundacji na Rzecz Nauki Polskiej. Seria Humanistyczna. Toruń: Fundacja na Rzecz Nauki Polskiej.

Vorbrich R. (2012). Plemienna i postplemienna Afryka. Koncepcje i postaci wspólnoty $w$ dawnej $i$ wspótczesnej Afryce. Seria Etnologia i Antropologia Kulturowa, 27, Poznań: Wydawnictwo Naukowe Uniwersytetu im. Adama Mickiewicza.
Wierzbicki A. (2011). Obcy w dziejach Polski. Hipoteza państwotwórczego podboju w polskiej myśli historycznej XIX i początków XX wieku. Klio Polska. Studia i materiaty z dziejów historiografii polskiej XIXXX wieku, 5, 119-149.

Wiszewski P. (2013). Posłowie do drugiego wydania. W kręgu dyskusji nad kryzysem państwa pierwszych Piastów. In: D. Borawska, Kryzys monarchii wczesnopiastowskiej wlatach trzydziestych XI wieku (172-187). Warszawa: Wydawnictwo Naukowe PWN.

Wyrozumski J. (2003). Miejsce archeologii w polskiej mediewistyce. In: Z. Woźniak, J. Gancarski (eds), Polonia Minor Medii Aevi. Studia ofiarowane Panu Profesorowi Andrzejowi Żakiemu w osiemdziesiata rocznicęurodzin (127-132). Kraków: PolskaAkademia Umiejętności \& Muzeum Podkarpackie.

Zajączkowski S. (2002). Podziały plemienne Polski w okresie powstania państwa. Geografia plemienna ziem polskich. In: K. Tymieniecki, G. Labuda, H. Łowmiański (eds), Początki państwa polskiego. Ksiega tysiaclecia (73-109), 1. Poznań: Poznańskie Towarzystwo Przyjaciół Nauk, reprint from 1962 edition.

Otrzymano (Received): 31.03.2020; Zrecenzowano (Revised): 11.04.2020; Zaakceptowano (Accepted): 29.11.2020

Author's address:

Prof. dr. hab. Michał Kara

Instytut Archeologii i Etnologii Polskiej Akademii Nauk

Ośrodek Studiów Pradziejowych i Średniowiecznych

(Institute of Archaeology and Ethnology of the Polish Academy of Sciences

Centre for Prehistoric and Medieval Studies)

ul. Rubież 46

61-612 Poznań

Poland

e-mail: michal.kara@iaepan.poznan.pl

(iD https://orcid.org/0000-0003-4541-5480 
